\title{
Population Change and Mobility: A Case Study of an Arkansas State Economic Area ${ }^{\dagger}$
}

$\mathrm{T}$ THE PHENOMENON of out-migration in various sections of the country had increased to such an extent by 1960 that approximately one-half of the counties in the nation had recorded a loss in population during the previous ten-year period. The outlook for the 1960's was for a continued out-migration and resulting population loss in most of these areas. The purpose of this study is to analyze that population mobility and change relative to the economy of Arkansas State Economic Area 7 (hereinafter referred to as SEA 7), a twelve-county, predominantly agricultural region in northeastern Arkansas.

Arkansas SEA 7 has experienced an increasing rate of net out-migration and population decline since the 1930's. While only three of the twelve counties in this region lost population in the 1920's and 1930's, ten did so in the 1940's and all twelve in the 1950's. Between 1950 and 1960, SEA 7 had a loss of 46,848 people, or 14.6 per cent of its total population. Since the natural increase during this period was about 53,000 , the net out-migration was nearly 100,000 , or 31.1 per cent. 1

This net out-migration has been most closely associated with the exodus from the farm. The rural population of SEA 7 had a decrease of about twenty-three per cent during the past decade but urban residents had an increase of more than eighteen per cent.

The loss of rural-farm and total inhabitants which began in the 1920's was not substantial until the 1940's. The effect of World War I in attracting persons to the industries of the North was relatively moderate. By World War II, however, many farmers had been battling the boll weevil and bad weather for years and were easily attracted by industry. Since there were few local industries which could be converted from peacetime to wartime production, many of the people left Arkansas to find work elsewhere, mainly in Michigan and California.

Although urban places in SEA 7 supplied many migrants, the attraction of the industrial North and West had much more impact on the rural areas. A large percentage of migrants during the 1940's never returned. Often entire families emigrated to make a new start in an industrial state. It was the "pull" of the factory from outside of Arkansas that was the primary force behind the initial widespread appearance of abandoned farmhouses.2 Concurrently, farms began to increase in size and mechanization became necessary.

Throughout the 1950's, the relative importance of industrial attraction declined and the significance of the "push" off the farm became dominant. The movement of small farmers off the land was a result mainly of mechanization on cotton plantations; the implementation of other laborsaving, scientific advances; and the inability of small farmers and share-croppers to compete successfully in the changing agrarian economy.

The acceleration of the movement off the farm in this latter period, plus the lack of sufficient industrial employment opportunities, resulted in a sharp rise in the unemployment and underemployment levels and put a heavier burden on the counties and the state for welfare funds. However, a moderate rise in manufacturing employment, together with a sharp drop in tenant farm-

+Field work for this study was conducted during 1967, while the author was teaching in the area at Arkansas State University. The author is indebted to Dr. C. W. Minkel, Professor of Geography at Michigan State University, for his helpful suggestions.

1 United States Bureau of the Census, Current Population Reports, Series P-23, No. 7, Components of Population Change, 1950-1960, for Counties, Standard Metropolitan Statistical Areas, State Economic Areas, and Economic Subregions, p. 69.

2 Ken Parker, "Arkansas is Going to Town," Arkansa Gazette (Little Rock), October 29, 1950, p. F-1. 
ers and share-croppers, were major contributors to a substantial gain in per-family income.

A comparison of net out-migration rates for the $1950-60$ and $1955-60$ periods shows an impressive drop in the latter half of the decade. Whereas the rate was 31.1 per cent for the entire ten-year period, it was only 8.0 per cent for the last five years. ${ }^{3}$ This means that, of the approximately 100,000 out-migrants of the 1950 's, only about 21,000 of these left SEA 7 in the second half of the decade. Nearly two-thirds of these latter out-migrants over five years of age were under the age of thirty.

From 1955 to 1960 , nonwhites had lower net out-migration rates than whites, thus reversing the trend of the first part of the decade. Not only did the total net outmigration rate decline toward the end of the 1950 's but this was even more true for the nonwhites.

There was in-migration from all states except Vermont and North Dakota; however, seventy-eight per cent of the total inmigrants came from Missouri, Michigan, Illinois, California, Tennessee, and other SEA's in Arkansas. Over ninety per cent of the nonwhite in-migrants came from Mississippi, Illinois, Missouri, Tennessee, Michigan, and other SEA's in Arkansas. ${ }^{4}$ Many of the white and nonwhite in-migrants returned to the region after having become disappointed in their new situations in other areas or after having heard of new jobs available near their original communities.

All states in the nation, except Vermont, received migrants from Arkansas SEA 7 between 1955 and 1960. Seventy-eight per cent of all out-migrants moved to other SEA's in Arkansas or to California, Missouri, Illinois, Tennessee, Texas, and Michigan. Approximately eighty-three per cent of the nonwhite out-migrants moved to other sections of Arkansas or to California, Illinois, Missouri, Indiana, and Michigan.5 Major migratory flow patterns, therefore, are between SEA 7 and California, the North Central states, and the states adjoining Arkansas. The changes in population which occurred for the decades between 1920 and 1960 presented a rather bleak outlook for SEA 7 . However, although some of the trends have continued since 1960, several of them have been reversed enough to permit a re-evaluation of the future of this region.

Mechanization has continued to displace large numbers of rural families. Farms have become even fewer in number, but larger in size. The number of acres in farms and the proportion of land in farms has increased in all but two of the counties. ${ }^{6}$ Therefore, agriculture is still expanding within the region. The major crops, namely cotton, rice, and soybeans, have been undergoing a change in relative importance within many of the counties. Cotton, which has long been the dominant crop in most of the region, has steadily lost ground to soybeans and rice. Falling market prices, decreasing government allotments for cotton, and poor weather since 1964 have resulted in a sharp decline in cultivated acreage of cotton and in income from cotton farming. Paralleling these changes has been the further abandonment of the tenant shack and the old farmhouse.

Although both the Census Bureau and the United States Department of Health, Education and Welfare predicted substantial losses of residents for Arkansas during the 1960's, because of the tremendous industrial promotion effort on the part of leading citizens and major organizations, such as the Chamber of Commerce, the population in most of the counties has been stabilized, or even increased slightly since 1960.7 Instead of continuing at the same rate of decline as in the 1950's, SEA 7 in the first half of the 1960's increased in population by 3.2 per cent, or by 8,729 persons. ${ }^{8}$ Whereas all twelve counties in the

\footnotetext{
8 United States Census Bureau, U. S. Census of Population: 1960. Subject Reports. Mobility for States and State Economic Areas, Final Report PC (2)-2B (Washington, D.C.: United States Government Printing Office, 1963).

Ibid.

I Ibid.

- United States Bureau of the Census, 1964 United States Census of Agriculture (Preliminary Reports for Arkansas, Clay, Craighead, Cross, Greene, Jackson, Lawrence, Lonoke, Monroe, Poinsett, Prairie, and Woodruff counties in Arkansas), Series AC 64-P1 (Washington, D.C.: United States Government Printing Office, September 1966), pp. 1-5.

T David Petty, "State Regains Most of Lost Population, Report Maintains," Arkansas Garette (Litle Rock), June 10, 1966, p. 15-A.

The Bureau of Business and Economic Research of the University of Arkansas, Arkansas Business Bulletin (Fayetteville, Univervity of Arkansas, May 1966), pp. 5.6.
} 
region lost population during the 1950's, only two showed a decline in the first half of the present decade. This was true even though the movement of families off the farms was still great. The increase in population, however, did not prevent net outmigration from occurring in every county except Craighead. The net in-migration of Craighead County was small and resulted chiefly from the increase in the student body at Arkansas State University in Jonesboro, the largest town $(26,000)$ in SEA 7 .

Most of the towns over 1,000 population have grown in number of residents since 1960. The rural-nonfarm population has also gained, since many of the former farmers and their families have chosen to continue living in their old farmhouses or to build new houses in the rural areas.

Opportunities for employment in manufacturing have increased considerably within most of the counties since 1960. Many new industrial installations have been established and several plants already in the region have expanded their operations. Although most of the new jobs have been for women, employment opportunities have been sufficient to stabilize or increase the population in all but two of the counties. In addition to the jobs made available in the new and expanding industries, the gain in population and income has also resulted in the creation of numerous non-manufacturing jobs, especially in wholesale and re- tail trade and services. The increase in employment, together with the tendency for many families to stay in rural areas, has resulted in a surge of commuting both within and among the various counties. Industrialization has definitely been the most significant factor in ending the decline of population in SEA 7 as a whole, and in all but two of its counties.

During the early 1960 's, county development councils were organized in most of the counties to work with local organizations in an attempt to improve employment opportunities, income, and living conditions. The councils and the local Chambers of Commerce have worked hard to advertise the attractions for industry in these counties, and communities have effectively used various special obligation revenue bonds in financing sites and buildings for new firms.

Although the future of SEA 7 is not filled with prospects for rapid industrial, economic, and population growth, it will be one of improved employment opportunities and income levels, of higher standards of education and training, and of better living conditions for most of the people. At least, the outlook for the future of the region is much brighter than most people anticipated in 1960.

D. Gordon BennetT

Assistant Professor of Geography

University of North Carolina

at Greensboro

\section{Some Evidence of the Intra-regional Structure of Interest Rates on Residential Mortgage Loans}

$\mathrm{T}^{\mathrm{s}}$ HIS PAPER presents the results of an attempt to determine empirically the structure of interest rates quoted at a given point in time on comparable mortgage loans in "large" and "small" cities in each of four regional mortgage markets in the United States: (1) in the river valleys connecting and including New York City and Buffalo; (2) in the region between and including Miami and Jacksonville; (3) in the region between and including Chicago and St.
Louis; and (4) in the region between and including Los Angeles and San Francisco. The objective is to provide some indication of the validity of the hypothesis proposed by Jones and Grebler that, in most regional mortgage markets, interest rates charged on given residential mortgage loans in the smaller cities will usually be significantly greater than interest rates charged on comparable loans in the large cities; in part because the allocation of funds for loans 